\title{
ANALISIS FAKTOR-FAKTOR YANG BERHUBUNGAN DENGAN PENGETAHUAN PERAWAT TENTANG PENCEGAHAN VENTILATOR ASSOCIATED PNEUMONIA (VAP) DI RUANG ICU RSUDDr. MOEWARDI
}

\author{
Akhmad Rifai \\ Politeknik Kesehatan Surakarta Jurusan Keperawatan
}

\begin{abstract}
Knowledge, Ventilator Associated Pneumonia (VAP). The use of mechanical ventilators often cause problems, such as lung infections, like pneumonia. The fact of the Center for Disesase Control (CDC), namely the prevention of Hospital Acquire Pneumonia (HAP) that most of the procedures to prevent VAP conducted by nurses. Nurses should have knowledge of how prevention of VAP. Where knowledge is influenced by several factors, including internal and external factors. The purpose of this study was to determine the factors associated with nurse's knowledge on the prevention of Ventilator Associated Pneumonia (VAP) in ICU of RSUD Dr. Moewardi Surakarta. The study was descriptive correlational with cross sectional approach. The results of this research indicate that there is no relationship between education with the knowledge of nurses on the preventing of VAP evidenced by the $r$ value of -0.036 count is smaller than $r$ table 0.4005. There was no relationship between years of service with the knowledge of nurses on the preventing of VAP evidenced by the $r$ value of 0.026 count is smaller than $r$ table 0.4005 . There was no relationship between training with the knowledge of nurses on the preventing of VAP evidenced by the $r$ value of -0.312 count is smaller than $r$ table 0.4005. There was no relationship between education, years of service, and training with the knowledge of nurses on the preventing of VAP.
\end{abstract}

Keywords : Knowledge, Ventilator Associated Pneumonia (VAP)

Abstrak : Pengetahuan, Ventilator Associated Pneumonia (VAP). Penggunaan ventilator mekanis sering menimbulkan permasalahan, diantaranya adalah infeksi paru, seperti pneumonia. Fakta dari Center for Disesase Control (CDC) yaitu pada pencegahan Hospital Acquire Pneumonia (HAP) bahwa sebagian besar prosedur untuk mencegah timbulnya VAP dilakukan oleh perawat. Perawat hendaknya mempunyai pengetahuan tentang bagaimana pencegahan VAP. Dimana pengetahuan tersebut dipengaruhi oleh beberapa faktor, meliputi faktor internal dan eksternal. Tujuan penelitian ini adalah mengetahui faktor-faktor yang berhubungan dengan pengetahuan perawat tentang pencegahan Ventilator Associated Pneumonia (VAP) di Ruang ICU RSUD Dr. Moewardi Surakarta. Jenis penelitian ini adalah deskriptif korelasional dengan pendekatan cross sectional. Hasil dari penelitian menunjukkan bahwa tidak ada hubungan antara pendidikan dengan pengetahuan perawat tentang pencegahan VAP dibuktikan dengan nilai $r$ hitung sebesar -0,036 lebih kecil dari $r$ tabel 0,4005. Tidak ada hubungan antara masa kerja dengan pengetahuan perawat tentang pencegahan VAP dibuktikan dengan nilai $r$ hitung sebesar 0,026 lebih kecil dari $r$ tabel 0,4005. Tidak ada hubungan antara pelatihan dengan pengetahuan perawat tentang pencegahan VAP 
dibuktikan dengan nilai $r$ hitung sebesar $-0,312$ lebih kecil dari $r$ tabel 0,4005. Tidak ada hubungan antara pendidikan, masa kerja, dan pelatihan dengan pengetahuan perawat tentang pencegahan VAP.

Kata Kunci : Pengetahuan, Ventilator Associated Pneumonia (VAP)

\section{PENDAHULUAN}

Pengetahuan dan kemampuan yang harus dimiliki oleh perawat ICU diantaranya dalam pengelolaan jalan nafas, termasuk penggunaan ventilator. Merawat pasien pada ventilator mekanis telah menjadi bagian integral dari asuhan keperawatan di unit perawatan kritis, di unit medikal bedah umum, di fasilitas perawatan yang luas, bahkan di rumah. Perawat, dokter, dan ahli terapis pernapasan harus mengerti masing-masing kebutuhan pernapasan spesifik pasien dan bekerja bersama-sama untuk membuat tujuan yang realistik (Smeltzer \& Bare, 2001). Penggunaan ventilator mekanis sering menimbulkan permasalahan, diantaranya adalah infeksi paru, seperti pneumonia. Pneumonia merupakan proses inflamatori parenkim paru yang umumnya disebabkan oleh agens infeksius (Smeltzer \& Bare, 2001). Infeksi saluran napas bawah ini masih menjadi masalah utama dalam bidang kesehatan, baik di negara yang sedang berkembang maupun yang sudah maju. Dari data SEAMIC Health Statistic 2001, influenza dan pneumonia merupakan penyebab kematian nomor 6 di Indonesia, nomor 9 di Brunei, nomor 7 di Malaysia, nomor 3 di Singapura, nomor 6 di Thailand dan nomor 3 di Vietnam. Laporan WHO 1999 menyebutkan bahwa penyebab kematian tertinggi akibat penyakit infeksi di dunia adalah infeksi saluran napas akut termasuk pneumonia dan influenza (PDPI, 2003). Pneumonia nosokomial adalah pneumonia yang didapat di rumah sakit. Pneumonia nosokomial terjadi 5-10 kasus per 1000 pasien yang masuk ke rumah sakit (Perhimpunan Dokter Paru Indonesia, 2003). Pneumonia nosokomial di ICU lebih sering daripada di ruangan umum yaitu $42 \%$ : $13 \%$, sebagian besar (47\%) terjadi pada pasien yang menggunakan ventilator mekanik (Dahlan, 1998). Dalam sumber lain disebutkan insiden pneumonia nosokomial 6 sampai 20 kali lebih tinggi pada pasien yang didukung dengan ventilator $\{\operatorname{Kim}(2010$, p. 1)\}. Angka kematian pada pneumonia nosokomial 2050\%. Angka kematian pasien pada pneumonia yang dirawat di istalansi perawatan intensif (IPI) meningkat 3-10x dibandingkan dengan pasien tanpa pneumonia (Perhimpunan Dokter Paru Indonesia, 2003). Bentuk infeksi nosokomial yang paling sering ditemui di unit perawatan intensif (UPI), khususnya pada penderita yang menggunakan ventilasi mekanik disebut dengan Ventilator associated pneumonia (VAP) \{Porzecanski, Bowton dan Chlebicki, Safdar (2006 dan 2007, dalam Wiryana, 2007, p. 255)\}.

\section{METODE PENELITIAN}

Desain yang digunakan dalam penelitian ini adalah deskriptif korelasional dengan pendekatan cross sectional Populasi dalam penelitian ini adalah semua perawat di Ruang ICU RSUD Dr. Moewardi Surakarta, yaitu sebanyak 25 perawat. Penelitian ini menggunakan alat ukur kuesioner dengan pertanyaan tertutup. 


\section{HASIL PENELITIAN}

Karakteristik responden dengan berdasarkan umur, jenis kelamin, pendidikan, masa kerja, pelatihan, dan pengetahuan perawat tentang pencegahan VAP dapat digambarkan sebagai berikut:

Karakteristik responden berdasarkan umur. Pada penelitian ini, dari 25 responden yang diteliti terdapat 4 responden $(16 \%)$ yang berumur $20-25$ tahun, 5 responden $(20 \%)$ yang berumur 26 - 30 tahun, 7 responden $(28 \%)$ yang berumur $31-35$ tahun, 6 responden (24\%) yang berumur $36-40$ tahun, dan 3 responden (12\%) yang berumur > 40 tahun. Distribusi frekuensi umur responden dapat dilihat pada tabel 8 di bawah ini.

\section{Tabel 1}

Distribusi frrekuensi Umur Responden

\begin{tabular}{|c|c|c|c|}
\hline No. & Umur & Jumlah & Persentase $(\%)$ \\
\hline 1. & $20-25$ tahun & 4 & 16 \\
\hline 2. & $26-30$ tahun & 5 & 20 \\
\hline 3. & $31-35$ tahun & 7 & 28 \\
\hline 3. & $36-40$ tahun & 6 & 24 \\
\hline 4. & $>40$ tahun & 3 & 12 \\
\hline & Total & 25 & 100 \\
\hline
\end{tabular}

berdasarkan jenis kelamin Pada penelitian ini, dari 25 responden yang diteliti terdapat 15 responden $(60 \%)$ yang berjenis kelamin laki-laki dan 10 responden $(40 \%)$ yang berjenis kelamin perempuan. Distribusi frekuensi jenis kelamin responden dapat dilihat pada tabel di bawah ini.

\section{Tabel 2}

\section{Distribusi Frekuensi Jenis Kelamin Responden}

\begin{tabular}{crcc}
\hline No. & Jenis Kelamin & Jumlah & Persentase (\%) \\
\hline 1. & Laki-laki & 15 & 60 \\
2. & Perempuan & 10 & 40 \\
\hline & Total & 25 & 100 \\
\hline & Karakteristik & & responden
\end{tabular}

berdasarkan pendidikan Pada penelitian ini, dari 25 responden yang diteliti terdapat 14 responden $(56 \%)$ yang berpendidikan D3 dan 11 responden (44\%) yang berpendidikan D4/S1. Distribusi frekuensi pendidikan responden dapat dilihat pada tabel 10 di bawah ini.

Tabel 3

Distribusi Frekuensi Pendidikan Responden

\begin{tabular}{|c|c|c|c|}
\hline No. & Pendidikan & Jumlah & $\begin{array}{c}\text { Persentase } \\
(\%)\end{array}$ \\
\hline 1. & D3 & 14 & 56 \\
\hline 2. & $\mathrm{D} 4 / \mathrm{S} 1$ & 11 & 44 \\
\hline \multicolumn{2}{|r|}{ Total } & 25 & 100 \\
\hline & Karakteristi & & respon \\
\hline
\end{tabular}

berdasarkan masa kerja Pada penelitian ini, dari 25 responden yang diteliti terdapat 11 responden (44\%) dengan masa kerja $0-5$ tahun, 7 responden (28\%) dengan masa kerja $6-10$ tahun, 4 responden $(16 \%)$ dengan masa kerja 11 15 tahun, dan 3 responden (12\%) dengan masa kerja > 15 tahun. Distribusi frekuensi masa kerja responden dapat dilihat pada tabel di bawah ini.

Tabel 4

\begin{tabular}{|c|c|c|c|}
\hline \multicolumn{4}{|c|}{$\begin{array}{c}\text { Distribusi Frekuensi Masa Kerja } \\
\text { Responden }\end{array}$} \\
\hline No. & $\begin{array}{l}\text { Masa } \\
\text { Kerja }\end{array}$ & Jumlah & Persentase (\%) \\
\hline 1. & $0-5$ th & 11 & 44 \\
\hline 2. & $6-10$ th & 7 & 28 \\
\hline 3. & $11-15$ th & 4 & 16 \\
\hline 4. & $>15$ th & 3 & 12 \\
\hline & Total & 25 & 100 \\
\hline
\end{tabular}

berdasarkan pelatihan Pada penelitian ini, dari 25 responden yang diteliti terdapat 2 responden $(8 \%)$ dengan pelatihan 0 kali, 18 responden $(72 \%)$ dengan pelatihan $1-$ 3 kali, 2 responden (8\%) dengan pelatihan 4 - 6 kali, dan 3 responden (12\%) dengan pelatihan $>6$ kali. 
Tabel 5

\section{Distribusi Frekuensi Pelatihan}

Responden

\begin{tabular}{crcc}
\hline No. & Pelatihan & Jumlah & Persentase (\%) \\
\hline 1. & 0 kali & 2 & 8 \\
2. & $1-3$ kali & 18 & 72 \\
3. & $4-6$ kali & 2 & 8 \\
4. & $>6$ kali & 3 & 12 \\
\hline Total & 25 & 100 & \\
\hline
\end{tabular}

Tabel 6

Distribusi Frekuensi Pengetahuan Responden

\begin{tabular}{|c|c|c|}
\hline No. & Pengetahuan & Jumlah \\
\hline 1. & Tinggi & 18 \\
\hline 2. & Sedang & 6 \\
\hline 3. & Rendah & 1 \\
\hline \multicolumn{2}{|r|}{ Total } & 25 \\
\hline
\end{tabular}
pendidikan dengan pengetahuan perawat tentang pencegahan VAP menggunakan uji non parametrik Rank Spearman dengan bantuan SPSS for windows versi 10.0 diperoleh hasil sebagai berikut:

Tabel 7

Hasil Uji Korelasi Pendidikan dengan Pengetahuan

\begin{tabular}{ccc}
\hline Variabel & r hitung & r tabel \\
\hline Pendidikan $*$ & $-0,036$ & 0,4005 \\
Pengetahuan & & \\
\hline Berdasarkan & tabel di & atas,
\end{tabular}
diperoleh perbandingan nilai $r$ hitung Rank Spearman sebesar -0,036, nilai $r$ tabel dengan $\mathrm{N}=25$ dan taraf signifikan 0,05 sebesar 0,4005 . Penghitungan $r$ tabel ini dilakukan secara manual dikarenakan dalam tabel nilai rho Spearman dengan $\mathrm{N}=25$ tidak dicantumkan.

Tabel 8

Hasil Uji Korelasi Masa Kerja dengan Pengetahuan

\begin{tabular}{ccc}
\hline Variabel & r hitung & r tabel \\
\hline $\begin{array}{c}\text { Masa Kerja } * \\
\text { Pengetahuan }\end{array}$ & 0,026 & 0,4005 \\
\hline
\end{tabular}

Berdasarkan tabel di atas, diperoleh perbandingan nilai $r$ hitung Rank Spearman sebesar 0,026, nilai $r$ tabel dengan $\mathrm{N}=25$ dan taraf signifikan 0,05 sebesar 0,4005. Karena $r$ hitung $<\mathrm{r}$ tabel $(0,026<0,4005)$ maka hipotesis Ho diterima dan Ha ditolak. Hal ini menunjukkan bahwa tidak ada hubungan antara masa kerja dengan pengetahuan perawat tentang pencegahan VAP di Ruang ICU RSUD Dr. Moewardi Surakarta Tahun 2011.

Persentase U\% menunjukkan kuat rendalmnya hubungan antara masa kerja dengtn pengetahuan perawat tentang peneegahan VAP di Ruang ICU RSUD Dr. Moewardi Surakarta Tahun 2011 dapat dilihat dalam interpretasi koefisien korelasi menurut Sugiyono (2007) pada tabel 15, dengan $r$ hitung sebesar 0,026 maka menunjukkan bahwa hubungan antara masa kerja dengan pengetahuan perawat tentang pencegahan VAP di Ruang ICU RSUD Dr. Moewardi Surakarta Tahun 2011 sangat rendah.

\section{Tabel 9}

Hasil Uji Korelasi Pelatihan dengan Pengetahuan

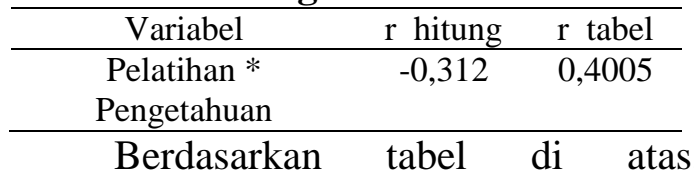
diperoleh perbandingan nilai $r$ hitung Rank Spearman sebesar -0,312, nilai $r$ tabel dengan $\mathrm{N}=25$ dan taraf signifikan 0,05 sebesar 0,4005.

Karena $r$ hitung $<r$ tabel $(0,312<$ 0,4005) maka hipotesis Ho diterima dan Ha ditolak. Hal ini menunjukkan bahwa tidak ada hubungan antara pelatihan dengan pengetahuan perawat tentang pencegahan VAP di Ruang ICU RSUD Dr. Moewardi Surakarta Tahun 2011. 
Untuk menunjukkan kuat rendahnya hubungan antara pelatihan dengan pengetahuan perawat tentang pencegahan VAP di Ruang ICU RSUD Dr. Moewardi Surakarta Tahun 2011 dapat dilihat dalam interpretasi koefisien korelasi menurut Sugiyono (2007) pada tabel 15, dengan $\mathrm{r}$ hitung sebesar 0,312 maka menunjukkan bahwa hubungan antara pelatihan dengan pengetahuan perawat tentang pencegahan VAP di Ruang ICU RSUD Dr. Moewardi Surakarta Tahun 2011 rendah.

\section{PEMBAHASAN}

Karakteristik pendidikan responden, dari 25 responden yang diteliti menunjukkan bahwa pendidikan responden sudah memenuhi standar profesi minimal, yaitu D3 dan sebagian sudah ada yang berpendidikan S1, serta sudah tidak ada lagi responden yang berpendidikan SPK. Hal ini dikarenakan tenaga kesehatan khususnya perawat diharapkan dapat terus meningkatkan mutu pelayanan kesehatan rumah sakit, salah satunya dengan meningkatkan pendidikan, di mana perawat diberikan kesempatan untuk melanjutkan pendidikan ke jenjang yang lebih tinggi.

Tujuan pendidikan SPK adalah meluluskan perawat kesehatan yang mampu sebagai pelaksana maupun pengelola keperawatan, yang saat ini sudah tidak ada lagi di Indonesia dan digantikan dengan jenjang pendidikan diploma tiga. Sedangkan tujuan dari D3 keperawatan adalah menghasilkan tenaga perawat profesional pemula yang mendapat sebutan ahli madya keperawatan yang merupakan manager menengah dalam keperawatan yang diharapkan mampu sebagai pelaksana, pengelola, pendidik dan partisipasi aktif dalam penelitian ilmiah. Adapun D4 merupakan jenis spesialisasi keperawatan disesuaikan dengan kebutuhan masyarakat dan perkembangan dalam bidang medis terutama keperawatan, dan S1 merupakan pendidikan akademik profesional (pendidikan keprofesian), menekankan pada penguasaan landasan keilmuan, yaitu ilmu keperawatan dan ilmu-ilmu penunjang, penumbuhan serta pembinaan sikap dan keterampilan profesional dalam keperawatan (Kusnanto, 2004), yang bertujuan untuk menghasilkan sarjana keperawatan sebagai perawat profesional yang mampu sebagai pelaksana, pengelola, pendidik, dan peneliti keperawatan (Priharjo, 1995).

Karakteristik masa kerja responden, dari 25 responden yang diteliti menunjukkan bahwa sebagian besar responden mempunyai masa kerja $0-5$ tahun, hal ini dikarenakan pihak RS banyak melakukan perekrutan perawatperawat baru dengan sistem kontrak dan juga adanya tambahan perawat baru yang diterima melalui jalur PNS. Seseorang yang mempunyai banyak pengalaman lapangan baik pengalaman yang positif maupun negatif, akan menambah kepekaannya terhadap masalah di bidangnya. Pengalaman-pengalaman yang diperolehnya langsung dari lapangan akan menambah keyakinan mereka, betapa serius masalah tersebut dan memperkuat usaha-usaha yang akan dilakukan untuk mengatasi masalah itu. Hal ini berarti dapat meningkatkan kepekaannya terhadap masalah yang bersangkutan dengan bidangnya (Notoatmodjo, 2005).

Karakteristik pelatihan responden, dari 25 responden yang diteliti menunjukkan bahwa sebagian besar responden telah mengikuti pelatihan sebanyak 1 - 3 kali, baik diselenggrakan 
dari pihak RS maupun dari luar RS. Pelatihan berkaitan dengan keahlian dan kemampuan pegawai dalam melaksanakan pekerjaan saat ini. Tujuan pelatihan menurut Tjiptono dan Diana (1998) adalah untuk meningkatkan pengetahuan, keterampilan, dan sikap karyawan serta meningkatkan kualitas dan produktivitas organisasi secara keseluruhan, dengan kata lain tujuan pelatihan adalah meningkatkan kinerja dan pada gilirannya akan meningkatkan daya saing.

Karakteristik pengetahuan responden, dari 25 responden yang diteliti menunjukkan bahwa sebagian besar responden berpengetahuan tinggi dan hanya sebagian kecil yang berpengetahuan rendah. Hal ini bisa disebabkan karena beberapa faktor. Salah satunya informasi, sebagaimana disampaikan oleh Suliha (2002) yang menjelaskan bahwa informasi merupakan salah satu faktor yang berhubungan dengan pengetahuan. Pengetahuan yang baik disebabkan oleh adanya informasi dari teman, radio, televisi, artikel, dan majalah juga dari pengalaman terdahulu \{Siagian (1996, dalam Suriani, 2010)\}.

Berdasarkan hasil perhitungan uji statistik menunjukkan bahwa tidak ada hubungan antara pendidikan, masa kerja, dan pelatihan dengan pengetahuan perawat tentang pencegahan VAP di Ruang ICU RSUD Dr. Moewardi Surakarta Tahun 2011. Sedangkan berdasarkan interpretasi koefisien korelasi menurut Sugiyono (2007) menunjukkan bahwa hubungan antara pendidikan dan masa kerja dengan pengetahuan perawat tentang pencegahan VAP di Ruang ICU RSUD Dr. Moewardi Surakarta Tahun 2011 sangat rendah, sedangkan hubungan antara pelatihan dengan pengetahuan perawat tentang pencegahan VAP di
Ruang ICU RSUD Dr. Moewardi Surakarta Tahun 2011 rendah.

$$
\text { Salah satu faktor yang }
$$

berhubungan dengan pengetahuan menurut Suliha (2002) adalah pendidikan. Pendidikan merupakan suatu proses yang sangat kompleks dengan tujuan akhir terjadi perubahan perilaku pada diri seseorang. Pendidikan merupakan unsur utama yang harus dilakukan, karena melalui pendidikan perkembangan profesi keperawatan akan lebih terarah dan berkembang sesuai dengan kemajuan ilmu dan teknologi sehingga tenaga keperawatan yang dihasilkan dapat berkualitas \{Aziz (2008, dalam Arum, 2010)\}.

Masa kerja (pengalaman) juga merupakan salah satu faktor yang berhubungan dengan pengetahuan (Suliha, 2002). Menurut Wursanto (2003, dalam Arum 2010) menjelaskan bahwa masa kerja adalah waktu kegiatan melakukan sesuatu, masa kerja biasa disebut pengalaman kerja, sedangkan pengalaman kerja adalah keseluruhan pembelajaran yang diperoleh seseorang selama perjalanan kerjanya. Begitu juga pelatihan, juga merupakan salah satu faktor yang berhubungan dengan pengetahuan (Suliha, 2002). Pelatihan sebagai proses pendidikan jangka pendek yang menggunakan cara dan prosedur yang sistematis dan terorganisir. Para peserta pelatihan akan mempelajari pengetahuan dan keterampilan yang sifatnya praktis untuk tujuan tertentu (Sumantri, 2000).

Pengetahuan responden sebagian besar tergolong tinggi. Hal ini tidak mutlak disebabkan karena faktor pendidikan, masa kerja, maupun pelatihan, tetapi bisa disebabkan karena faktor-faktor lain yang berhubungan 
dengan pengetahuan. Pengetahuan responden yang tergolong tinggi ini, bisa disebabkan karena informasi yang telah responden dapatkan, baik dari media cetak maupun elektronik, serta sumber informasi lain yang bisa menambah pengetahuan responden. Dari teori Health Belief Model (HBM) menyatakan bahwa tingkat pengetahuan seseorang dipengaruhi oleh informasi dan lingkungan melalui proses. Setelah mendapatkan informasi dari luar seseorang akan mengingat materi tersebut untuk dipelajari, adanya kemampuan untuk menjelaskan secara benar tentang materi tersebut dan kemampuan untuk menggunakan materi yang telah dipelajari pada situasi atau kondisi riil. Selanjutnya menjabarkan materi atau suatu obyek ke dalam komponen yang masih ada kaitannya satu sama lain, menyusun informasi baru dari formulasi yang telah ada dan melakukan penelitian terhadap suatu materi \{Notoatmodjo (2002, dalam Suriani, 2010)\}.

Menurut Bidaulph (1999, dalam Suliha, 2002) menjelaskan bahwa pengetahuan dapat juga berasal dari informasi yang tidak tersusun secara baik yaitu melalui pembicaraan teman-teman dan keluarga, membaca majalah, surat kabar, mendengar radio, melihat televisi, serta berdasarkan pengalaman sendiri. Seseorang yang mempunyai sumber informasi yang lebih banyak akan memberikan pengetahuan yang jelas.

Tidak adanya hubungan antara pendidikan, masa kerja, dan pelatihan ini juga bisa disebabkan karena sampel penelitian yang sedikit, sehingga belum bisa menggambarkan hasil penelitian tentang faktor-faktor yang berhubungan dengan pengetahuan perawat tentang pencegahan VAP. Hal ini didukung dengan penelitian yang dilakukan oleh Yuanda (2010) tentang hubungan karakteristik perawat dengan sikap penanganan kegawatan nafas pada neonates yang mengalami kegawatan nafas di Ruang PICU/NICU RSUD Dr. Moewardi Surakarta, dengan sampel sebanyak 15 responden perawat PICU/ NICU. Hasil dari penelitian menunjukkan bahwa tidak ada hubungan antara karakteristik umur dengan sikap responden dalam penanganan kegawatan nafas pada neonates yang mengalami kegawatan nafas pada neonates yang mengalamni kegawatan dengan nilai Uji Chi Square sebesar 0,195, lebih besar dari nilai $\alpha=0,05$. Tidak ada hubungan antara karakteristik pendidikan dengan sikap responden dengan nilai Kendall's Tau sebesar 0,812. Tidak ada hubungan antara karakteristik masa kerja dengan sikap responden dengan nilai Kendall's Tau sebesar 0,813 .

Hal ini juga didukung dari penelitian Arum (2010) tentang hubungan karakteristik perawat terhadap partisipasi perawat dalam proses keperawatan kegawatdaruratan trauma kepala di ruang UGD RSUD Belitung Timur, dengan sampel sebanyak 12 responden perawat UGD. Hasil dari penelitian menunjukkan bahwa ada hubungan negatif antara karakteristik usia perawat dengan partisipasi perawat dibuktikan dengan nilai $r$ hitung sebesar $-0,849$ lebih besar dari $r$ tabel 0,591. Tidak ada hubungan antara karakteristik masa kerja perawat dengan partisipasi perawat dibuktikan dengan nilai $r$ hitung sebesar 0,556 lebih kecil dari $r$ tabel 0,591. Ada hubungan signifikan antara pendidikan perawat dengan partisipasi perawat dibuktikan dengan nilai $r$ hitung sebesar 0,657 lebih besar dari $r$ tabel 0,591. 
Tidak adanya hubungan antara pendidikan, masa kerja, dan pelatihan ini juga bisa disebabkan karena ketiga faktor ini saling mempengaruhi dan melengkapi satu dengan yang lainnya. Di mana pengetahuan yang telah responden dapatkan dari tingkat pendidikan yang berbeda, akan bisa dilengkapi dengan adanya pelatihan-pelatihan yang responden ikuti seiring dengan bertambahnya masa kerja responden. Sehingga kekurangan masing-masing faktor yang hasil akhirnya sama-sama tercapainya pengetahuan ini akan bisa tertutupi.

\section{KESIMPULAN DAN SARAN}

1. Tidak ada hubungan antara pendidikan dengan pengetahuan perawat tentang pencegahan VAP.

2. Tidak ada hubungan antara masa kerja dengan pengetahuan perawat tentang pencegahan VAP.

3. Tidak ada hubungan antara pelatihan dengan pengetahuan perawat tentang pencegahan VAP.

Bagi perawat ICU RSUD Dr. Moewardi Surakarta diharapkan terus meningkatkan dan memperbarui pengetahuan tentang VAP yang telah dimiliki, sehingga akan tercapai pengetahuan yang lebih baik.

Penelitian selanjutnya diharapkan dapat lebih meningkatkan jumlah sampel penelitian dan lebih mengembangkan variabel penelitian, serta memodifikasi bentuk kuesioner, misalnya dengan pertanyaan terbuka ataupun dengan pilihan jawaban multipel choice sehingga lebih bisa menggali pengetahuan yang dimiliki masing-masing responden, serta dalam pengisian kuesioner diharapkan bisa ditunggui sehingga bisa didapatkan hasil yang benar-benar valid dari masingmasing responden.

\section{DAFTAR RUJUKAN}

Arum, P.P. (2010). Skripsi "Hubungan Karakteristik Perawat terhadap Partisipasi Perawat dalam Proses Keperawatan Kegawatdaruratan Trauma Kepala”. Surakarta: Poltekkes Surakarta.

Dahlan, Z. (1998). Tinjauan Ulang Masalah Pneumonia yang Didapat di Rumah Sakit. Juli 30, 2010. Bagian/SMF Ilmu Penyakit Dalam Fakultas Kedokteran Universitas Padjadjaran RSUP Dr. Sadikin Bandung. http://www.kalbe.co.id.

Hadi, S. (2004). Metodologi Research, Jilid 2. Yogyakarta: ANDI.

KARS. (2006). Standar Pelayanan Rumah Sakit, Instrumen Penilaian Akreditasi RS. Bandung : Pelayanan Intensif.

Kim, L.S. (2010, July 29), Jurnal Critical Care Nurses' Knowledge in Preventing Nosocomial Pneumonia,1-10. Juli 30, 2010. http://www.findarticles.com.

Kusnanto. (2004). Pengantar Profesi \& Praktik Keperawatan Profesional. Jakarta: EGC.

Notoatmodjo, S. (2002). Metodologi Penelitian Kesehatan, Edisi Revisi. Jakarta: Rineka Cipta.

Pariani, S. (2001). Metodologi Penelitian. Jakarta: Penerbit Andi Offset.

PDPI. (2003). Pneumonia Komuniti. Juli 30, $2010 . \quad$ PDPI. http://www.klikpdpi.com.

Priyatno, D. (2008). Mandiri Belajar SPSS. Yogyakarta: MediaKom.

Riri. (2009). Appraising Journal. September $\quad 3$, 2010. 
http://www.ririsimplyinfo.blogspot .com.

Rivai, V. (2004). Manajemen Sumber Daya Manusia Untuk Perusahaan. Jakarta: PT. Raja Grafindo Persada.

Smeltzer, S.C. \& Bare, B.G. (2001). Buku Ajar Keperawatan Medikal Bedah Brunner \& Suddarth, Edisi 8, Vol. 1. Jakarta : EGC.

Sugiyono. (2007). Statistik Untuk Penelitian. Bandung: CV. Alfabeta.

Suliha, U. (2002). Pendidikan Kesehatan dalam Keperawatan. Jakarta: EGC.

Sumantri, S. (2000). Pelatihan dan Pengembangan Sumber Daya Manusia. Bandung: Fakultas Psikologi Unpad.

Suriani. (2010). Skripsi "Hubungan Pengetahuan Perawat tentang Kegawatdaruratan Trauma Kepala dengan Sikap Perawat dalam Manajemen Kegawatdaruratan pada Pasien Trauma Kepala Di IGD RSUD Nunukan, Kalimantan Timur". Surakarta: Poltekkes Surakarta.
Tjiptono, F., \& Diana, A. (1998). Total Quality, Management. Yogyakarta: Andi offset.

Wiryana. (2007, September). Jurnal Penyakit Dalam, Ventilator Associated Pneumonia, 8 (3), 254265. Juli 30, 2010. http://www.ejournal.unud.ac.id.

Yuanda, R. (2010). Skripsi "Hubungan Karakteristik Perawat dengan Sikap Penanganan Kegawatan Nafas pada Neonates yang Mengalamni Kegawatan Nafas di Ruang PICU/ NICU RSUD Dr. Moewardi Surakarta". Surakarta: Poltekkes Surakarta. 